\title{
STUDIES ON THE IMMUNOCHEMICAL BASIS OF ALLERGIC REACTIONS TO DEXTRAN IN MAN ${ }^{1,2}$
}

\author{
BY ELVIN A. KABAT, GERARD M. TURINO,3 ARTHUR B. TARROW, AND
} PAUL H. MAURER

\author{
(From the Departments of Microbiology and Neurology, College of Physicians and Surgeons, \\ Columbia University and the Neurological Institute, Presbyterian Hospital, New York, \\ N. Y.; the National Research Council, Washington, D. C.; the Lackland Air Force \\ Base Hospital, San Antonio, Tex.; and the Department of Pathology, \\ University of Pittsburgh, Pittsburgh, Penna.)
}

(Submitted for publication February 19, 1957; accepted March 28, 1957)

Early in the use of certain purified dextran solutions as plasma volume expanders in the treatment of shock in man, it was observed that immediate type allergic reactions could be produced $(1-4)$. The then available clinical dextrans of Swedish and British origin had been found to give a high incidence of allergic reactions, while a product of American manufacture produced a very low incidence $(3,4)$. The reason for this difference remained obscure.

Studies on the antigenicity of purified dextrans showed them to be non-antigenic in the rabbit $(5,6)$ and guinea pig $(6)$, whereas initial injection in rats gave an unusual type of allergic reaction (7-9) characterized by rapid onset of edema of the paws and snout.

Studies by Kabat and Berg $(10,11)$ which were confirmed by Maurer (12) demonstrated that highly purified dextrans were antigenic in man and that injection of $1 \mathrm{mg}$. of native or clinical dextran gave rise to precipitating antibodies and resulted in the development of wheal and erythema type skin sensitivity. It was further

\footnotetext{
1 The data in this paper were presented in reports to the National Research Council Subcommittee on Shock by Drs. E. A. Kabat, G. M. Turino and A. B. Tarrow in January and April, 1952, and by Dr. P. H. Maurer in an interim report to the Chief, Research and Development Division, Office of the Surgeon General, U. S. Army, dated June 1, 1954.

2 Aided in part by a grant from the William J. Matheson Commission and the Office of the Surgeon General, Department of Army Contract DA-49-007-MD-248 upon recommendation of the Subcommittee on Shock of the National Research Council.

${ }^{8}$ Work done while Captain, U. S. Air Force Medical Corps and Staff member, Division of Medical Sciences, National Research Council. Present Address: Department of Medicine, College of Physicians and Surgeons, Columbia University, New York, N. Y.
}

shown that a significant proportion of individuals showed small amounts of precipitating antibody to dextran (cf. 13) and wheal and erythema type sensitivity before any known deliberate contact with dextran.

In view of the interest in dextran solution as a plasma volume expander in the therapy of shock, and since the basis of the systemic reactions to dextran was not understood, and methods of commercial manufacture of dextran solution frequently failed to yield products which did not produce allergic reactions, it became important to evaluate the possible role of existing skin sensitivity and circulating antibody to dextran in relation to systemic reactions to infusions of dextran in a group of normal individuals. A cooperative study sponsored by the Subcommittee on Shock of the National Research Council and the Armed Services was undertaken. ${ }^{1}$

Earlier findings $(3,4)$ were confirmed that the incidence of generalized allergic reactions varied quite sharply with the type of dextran and manufacturing process used at that time. With a dextran giving a high incidence of systemic allergic reactions on intravenous infusion, a high statistical correlation was found between allergic reactions and initial skin sensitivity to certain native dextrans and also between allergic reactions and initial circulating precipitin levels as determined with certain dextrans. Clinical dextrans gave a low incidence of positive skin test reactions, whereas native dextrans gave a high incidence of positive reactions. Hehre and Neill (cited in Reference 2) had noted some positive skin reactions to native dextran in man.

A correlation between the incidence of skin sensitivity and the structure of the native dextran was also found. From an interpretation of the 
findings, it became possible to define the basis of specifications for clinical dextran manufacture with respect to selection of Leuconostoc mesenteroides strain, and upper and lower limits of molecular size. Adherence to these specifications permitted the manufacture of dextran giving a negligible incidence of allergic reactions in clinical use.

\section{Materials}

\section{METHODS}

A. Clinical dextrans for infusion were:

1) Swedish dextran Pharmacia Co. Lots $5402 Y$

$$
\text { Z } 6932 \text { A }
$$

A 8745 C

2) Commercial Solvents Corporation dextrans.

Lot No. $255 \mathrm{~F} 4-$ molecular weight by light scattering 4

Average, 59,000

High, 10.6 per cent 175,000

Low, 12.3 per cent 22,780

Lot No. 258A7

Average, 87,800

High, 11.3 per cent 263,000

Low, 8.9 per cent 25,700

3) NRRL B742 clinical

Average, 61,000

High, 7.8 per cent 100,000

Low, 7.9 per cent 30,000

Swedish dextran was produced by a strain of $L$. mesenteroides which yielded a native dextran $\left(3079^{\top}\right)$ with 88 per cent $1 \rightarrow 6$-like, 5 per cent $1 \rightarrow 4$-like and 7 per cent $1 \rightarrow 3$-like linkages, giving a ratio of $1 \rightarrow 6$ to non$1 \rightarrow 6$ linkages of 7.5 (14), while the Commercial Solvents Corporation dextran was prepared from the NRRL B512 strain which yielded a dextran containing 96 per cent of $1 \rightarrow 6$ linkages and 4 per cent of $1 \rightarrow 3$ like linkages (15) to give a ratio of 24. Lot 258A7 was deliberately prepared to have higher average and upper fraction molecular weights than the usual clinical Commercial Solvents dextran.

Data supplied by the Pharmacia Company and by Dr. S. G. Weissberg of the National Bureau of Standards (cf. National Bureau of Standards Report 1160 [1951]) indicated that batch 150 had 8.1 per cent, and batch 156 had 4.0 per cent of material with an intrinsic viscosity of 0.395 ; batch 168 had 5 per cent of material with an intrinsic viscosity of 0.364 . From the data of Ingelman and Halling (16), Dr. Michael Wales found an intrinsic viscosity of 0.390 to correspond to a sedimentation constant of 6.4 or a molecular weight of 210,000 for a comparable Swedish dextran batch 155 . On fractionation of

4 Data supplied by Dr. S. G. Weissberg, National Bureau of Standards, and Dr. F. Senti, Northern Regional Research Laboratory of the Department of Agriculture. a similar batch of Swedish dextran Y5740A which was studied by sedimentation equilibrium it was estimated that about 0.3 per cent of the material had a molecular weight greater than 500,000 . Thus the Swedish preparations in the study contained appreciable amounts of higher molecular weight material than did Commercial Solvents dextran lot $255 \mathrm{~F} 4$.

B. Dextrans for skin tests: Saline solutions containing $1 \mathrm{mg}$. per ml. of native dextrans NRRL B742, B1255, B512 from Dr. Allene Jeanes, native Swedish dextran 3079, clinical Commercial Solvents dextran and those Swedish clinical dextrans used above were prepared with 0.25 per cent phenol as preservative. A solution of Leuconostoc protein from an ultrasonically disintegrated culture of $L$. mesenteroides strain D grown on sucrosefree media after three passages through dextrose broth, was kindly supplied by Dr. Joel Warren of the Army Medical Graduate School at Walter Reed Army Medical Center, and was prepared for skin testing in a similar manner, and used at a concentration of $10 \mu \mathrm{g}$. protein per $\mathrm{ml}$. (1.6 $\mu \mathrm{g}$. $\mathrm{N}$ per $\mathrm{ml}$.). Phenolized saline was used as a control. The nitrogen contents of native dextrans NRRL B742, B1255, B512 and native Swedish dextran were $0.003,0.025,0.004$ and 0.05 per cent, respectively; these data are tabulated in references 10 and 11 . Clinical dextrans are required to have less than 0.016 per cent $N$ to be acceptable for use in man.

\section{Experimental subjects}

Two hundred and seven Air Force inductees, 17 to 26 years of age, who had never received an infusion of dextran volunteered for the experiment. From 51 of these the routine course of immunization required on induction was withheld until after the completion of the study. In addition, 33 subjects who had received dextran infusions from 4 to 23 months previously in earlier studies $(3,4)$ volunteered to receive a second infusion. The combined results of the two studies carried out three months apart in January and April, 1952, are presented.

\section{Design of experiment}

Studies were carried out in a ward at the Lackland Air Force Base Hospital, San Antonio, Texas, except for a small number of the re-infusions which were carried out at the Walter Reed Army Medical Center, Washington, D. C. Groups of approximately 50 subjects were studied at one time. An initial blood sample of $200 \mathrm{ml}$. was taken sterilely. The serum from these bleedings was prepared, frozen and shipped to Dr. Paul H. Maurer at the University of Pittsburgh by air express. Upon receipt of the sera, phenol to 0.25 per cent and merthiolate to a concentration of $1: 10,000$ were added and the sera kept frozen until used. Each subject then received nine intracutaneous injections of the various native or clinical dextrans, Leuconostoc protein, or phenolized saline along both arms. The 101 subjects in the first study were not skin tested with Leuconostoc protein. Resulting wheal and erythema reactions were evaluated 15 to 20 minutes later and were graded from negative to $4+$, 
based on measurements of the diameter of the wheal and erythema reaction. Doubtful reactions were graded \pm . Following the reading of the skin tests, infusion of dextran by vein was started; 20 to 30 minutes were required for administration of $500 \mathrm{ml}$. of 6 per cent dextran. Individuals were observed closely for the appearance of signs and symptoms of allergic reactions. Symptoms and signs resembled those described in detail by Tarrow (4) and others (1-3) and included flushing, headache, urticaria and angioneurotic edema, rhinitis, lacrimation, tightness of chest, wheezing and pulmonary rales, hypotension and syncope on standing, swelling of extremities, nausea and vomiting. Systemic reactions were classified as mild, moderate or severe depending upon the number and severity of the signs and symptoms. A conspicous feature of the systemic reaction was that a flare-up of the positive skin test sites was frequently noted. When systemic reactions appeared rapidly and were of appreciable severity, infusion of dextran, was discontinued and Benadrylio and/or ephedrine were administered parenterally, as indicated. Subjects remained under observation for about 24 hours. Delayed skin reactions were not studied and only occasional subjects reported symptoms 18 hours or longer after infusion. Tarrow (4) reported pain in joints, abdominal cramps and aching shoulders in a small proportion of cases up to 24 hours post infusion. One month after infusion a second 200-ml. blood sample was taken and processed as above. This procedure was also followed with the 33 individuals who received re-infusions of dextran. This group, however, was divided so that half of the 15 individuals who had received an earlier infusion of Swedish dextran received a second infusion of Swedish dextran and the other half received Commercial Solvents dextran; while all 18 individuals who had previously had Commercial Solvents dextran and one who had previ-

TABLE I

Relation of skin sensitivity to intracutaneous injection of various dextrans, and systemic allergic reactions on infusion of dextran

\begin{tabular}{|c|c|c|c|c|c|}
\hline \multirow[b]{2}{*}{ Dextran used for skin test } & \multirow[b]{2}{*}{ Skin test* } & \multicolumn{2}{|c|}{ Systemic reactions } & \multirow[b]{2}{*}{$x^{2}$} & \multirow[b]{2}{*}{ Pt } \\
\hline & & Negative & Positive & & \\
\hline \multicolumn{6}{|c|}{ Experiment 1-Infusion Swedish Dextran } \\
\hline Native Swedish 3079 & $\overline{+}$ & $\begin{array}{r}45 \\
5\end{array}$ & $\begin{array}{l}26 \\
25\end{array}$ & 16 & $<0.00004$ \\
\hline NRRL B1255 & $\overline{+}$ & $\begin{array}{r}41 \\
9\end{array}$ & $\begin{array}{l}21 \\
30\end{array}$ & & \\
\hline NRRL B742 & $\bar{t}$ & $\begin{array}{l}24 \\
26\end{array}$ & $\begin{array}{r}4 \\
47\end{array}$ & 18 & $<0.00004$ \\
\hline $\begin{array}{l}\text { NRRL B512 (Native Commercial } \\
\text { Solvents) }\end{array}$ & $\overline{+}$ & $\begin{array}{r}48 \\
2\end{array}$ & $\begin{array}{r}44 \\
7\end{array}$ & 2 & $>0.05$ \\
\hline Clinical Swedish & $\bar{t}$ & $\begin{array}{r}49 \\
1\end{array}$ & $\begin{array}{r}48 \\
3\end{array}$ & & \\
\hline Clinical Commercial Solvents & $\bar{t}$ & $\begin{array}{r}49 \\
1\end{array}$ & $\begin{array}{r}48 \\
3\end{array}$ & & \\
\hline \multicolumn{6}{|c|}{ Experiment 2-Infusion Commercial Solvents Dextran } \\
\hline Native Swedish 3079 & $\bar{t}$ & $\begin{array}{l}40 \\
51\end{array}$ & $\begin{array}{r}2 \\
14\end{array}$ & 4.8 & 0.025 \\
\hline NRRL B1255 & $\bar{t}$ & $\begin{array}{l}20 \\
71\end{array}$ & $\begin{array}{r}2 \\
14\end{array}$ & & \\
\hline NRRL B742 & $\bar{t}$ & $\begin{array}{l}10 \\
81\end{array}$ & $\begin{array}{r}0 \\
16\end{array}$ & & \\
\hline $\begin{array}{l}\text { NRRL B512 (Native Commercial } \\
\text { Solvents) }\end{array}$ & $\bar{t}$ & $\begin{array}{l}63 \\
28\end{array}$ & $\begin{array}{l}7 \\
9\end{array}$ & 2.8 & 0.1 \\
\hline Clinical Swedish & $\overline{+}$ & $\begin{array}{r}82 \\
9\end{array}$ & $\begin{array}{l}7 \\
9\end{array}$ & 17.6 & 0.00017 \\
\hline Leuconostoc protein & $\bar{t}$ & $\begin{array}{l}10 \\
81\end{array}$ & $\begin{array}{r}1 \\
15\end{array}$ & & \\
\hline
\end{tabular}

$* \pm$ reactions were tabulated as negative.

$\dagger \mathrm{P}=0.002$ for $x^{2}=10.0$ with one degree of freedom. 
ously received British dextran, received a second infusion of Commercial Solvents dextran.

Quantitative precipitin tests were carried out by the Heidelberger and MacPherson (17) micromodification of the quantitative precipitin test, using quantities of the various native or clinical dextrans (10-12). Although $3.0 \mathrm{ml}$. of serum was used for each analysis the results are expressed in micrograms of antibody nitrogen per ml. of serum.

\section{RESULTS}

Results as presented are a summary of the findings. Complete observations on each individual and the antibody analyses appear in the reports to the National Research Council. ${ }^{1}$

Of the 101 individuals who received an infusion of Swedish dextran, 32 showed mild reactions, 15 moderate and 4 showed severe reactions. No difference in incidence of reactions related to the routine Armed Forces immunizations was found. Of 100 individuals who received Commercial Solvents dextran, 12 showed mild reactions and 2 showed severe reactions. Many of the mild reactions consisted only of one or two hives. The two severe reactions with Commercial Solvents dextran occurred in the group of 30 individuals who had received Commercial Solvents dextran, lot 258A7 with the higher molecular weight range. Of the 7 individuals who received clinical NRRL B742 dextran, one showed a mild and one a moderate reaction.

Table I shows the incidence of skin sensitivity to the various dextrans used for skin tests in individuals who showed positive and negative systemic reactions.

Figure 1 summarizes the distribution among the systemic reactors and non-reactors with respect to the severity of the skin test. The degree of the systemic reactions is also indicated. It is clearly evident from Table I that there is a high degree of correlation between systemic allergic reactions to infusion of Swedish dextran and previously existing skin sensitivity to native Swedish dextran and to native dextrans NRRL B1255 and B742. Native NRRL B512 and the two clinical dextrans gave much lower incidences of initial skin sensitivity and no correlation with systemic reactions was found.

In the group of individuals who received infusions of Commercial Solvents dextran, a high correlation with pre-existing skin sensitivity to clinical Swedish dextran and a moderate correla-

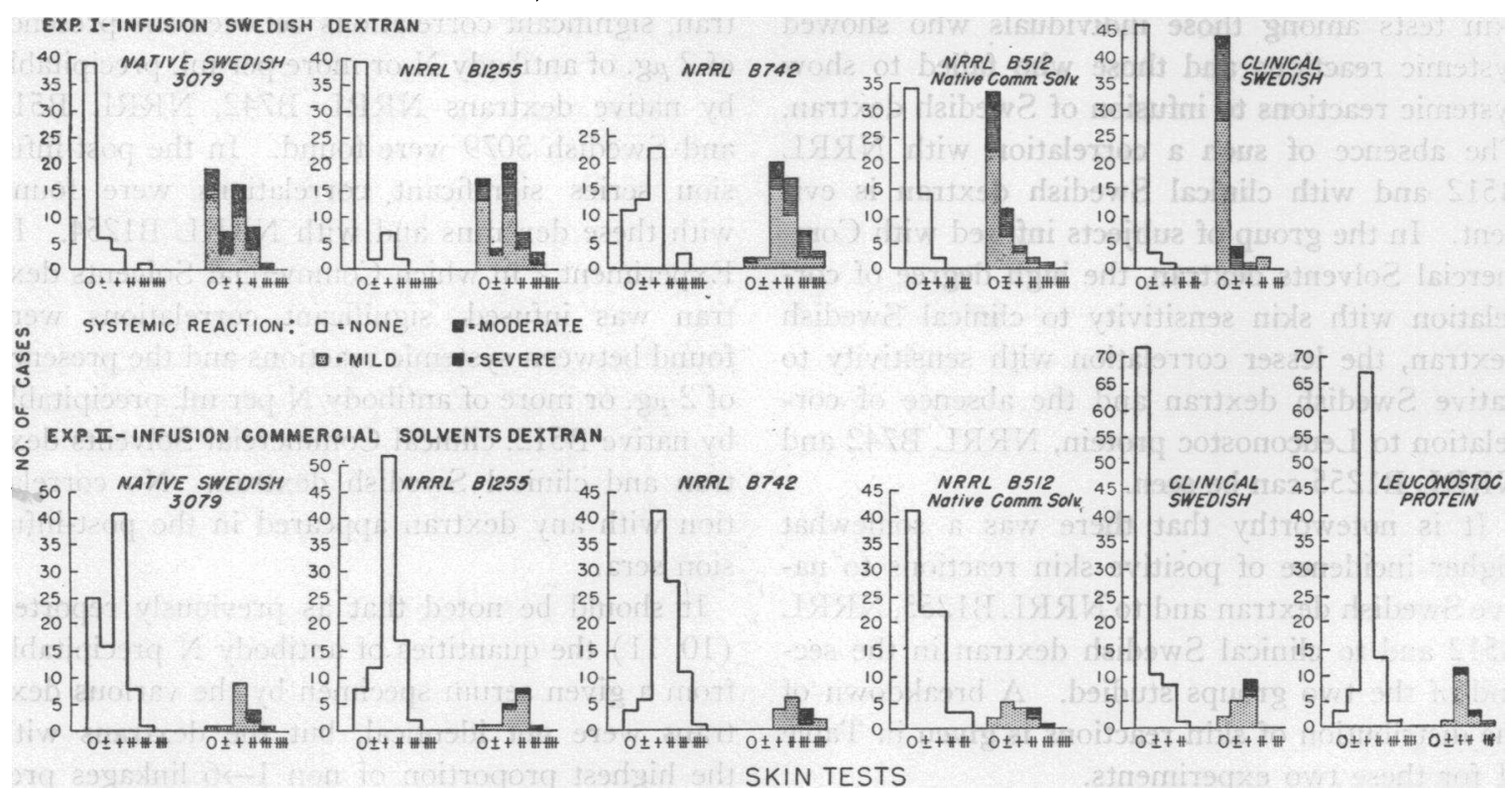

Fig. 1. Distribution of Skin Tests to Various Dextrans in Reration to Systemic Reactions on SubSEQUENT INFusion OF Dextran

For each dextran the unshaded areas represent the non-reactors and the shaded areas the degree of system reaction as indicated. 
TABLE II

Distribution of pre-existing skin reactions in individuals studied in experiments 1 and 2

\begin{tabular}{|c|c|c|c|c|c|c|c|}
\hline \multirow[b]{2}{*}{ Dextran } & \multirow{2}{*}{$\begin{array}{c}\text { Experiment } \\
\text { number }\end{array}$} & \multicolumn{6}{|c|}{$\frac{\text { Degree of skin sensitivity }}{\text { (Number of individuals) }}$} \\
\hline & & - & \pm & + & ++ & +++ & ++++ \\
\hline Native Swedish 3079 & $\begin{array}{l}1 \\
2\end{array}$ & $\begin{array}{l}58 \\
25\end{array}$ & $\begin{array}{l}13 \\
17\end{array}$ & $\begin{array}{l}20 \\
52\end{array}$ & $\begin{array}{r}9 \\
11\end{array}$ & $\begin{array}{l}1 \\
2\end{array}$ & \\
\hline NRRL B1255 & $\begin{array}{l}1 \\
2\end{array}$ & $\begin{array}{r}56 \\
9\end{array}$ & $\begin{array}{r}6 \\
13\end{array}$ & $\begin{array}{l}27 \\
60\end{array}$ & $\begin{array}{r}9 \\
23\end{array}$ & $\begin{array}{l}3 \\
2\end{array}$ & \\
\hline NRRL B742 & $\begin{array}{l}1 \\
2\end{array}$ & $\begin{array}{r}10 \\
3\end{array}$ & $\begin{array}{r}15 \\
7\end{array}$ & $\begin{array}{l}42 \\
43\end{array}$ & $\begin{array}{l}17 \\
31\end{array}$ & $\begin{array}{l}10 \\
13\end{array}$ & $\begin{array}{l}3 \\
3\end{array}$ \\
\hline NRRL B512 & $\begin{array}{l}1 \\
2\end{array}$ & $\begin{array}{l}67 \\
42\end{array}$ & $\begin{array}{l}25 \\
28\end{array}$ & $\begin{array}{r}6 \\
25\end{array}$ & $\begin{array}{l}2 \\
9\end{array}$ & $\begin{array}{l}1 \\
3\end{array}$ & \\
\hline Clinical Swedish & $\begin{array}{l}1 \\
2\end{array}$ & $\begin{array}{l}90 \\
74\end{array}$ & $\begin{array}{r}7 \\
15\end{array}$ & $\begin{array}{r}2 \\
17\end{array}$ & $\begin{array}{l}2 \\
1\end{array}$ & & \\
\hline Leuconostoc protein & 2 & 3 & 8 & 78 & 10 & 2 & \\
\hline
\end{tabular}

tion to pre-existing skin sensitivity to native Swedish dextran was found. No significant correlation could be demonstrated with Leuconostoc protein or the other dextrans. The high degree of significance with respect to skin sensitivity and allergic reactions is further illustrated in Figure 1. It can be seen that with native Swedish dextran 3079, NRRL B1255 and NRRL B742, there is a striking difference in the distribution of positive skin tests among those individuals who showed systemic reactions and those who failed to show systemic reactions to infusion of Swedish dextran. The absence of such a correlation with NRRL B512 and with clinical Swedish dextran is evident. In the group of subjects infused with Commercial Solvents dextran, the high degree of correlation with skin sensitivity to clinical Swedish dextran, the lesser correlation with sensitivity to native Swedish dextran and the absence of correlation to Leuconostoc protein, NRRL B742 and NRRL B1255 can be seen.

It is noteworthy that there was a somewhat higher incidence of positive skin reactions to native Swedish dextran and to NRRL B1255, NRRL B512 and to clinical Swedish dextran in the second of the two groups studied. A breakdown of the distribution of skin reactions is given in Table II for these two experiments.

It is also of interest that the incidence of positive skin tests of individuals before infusion of dextran was higher with those native dextrans having a higher proportion of non $1 \rightarrow 6$ linkages. The pro- portion of positive skin tests was unrelated to the nitrogen content of the native dextrans, B742 with the lowest nitrogen giving the highest incidence of positive skin reactions.

Table III summarizes data on the relation between systemic allergic reactions and circulating precipitins to various dextrans before infusion and one month after infusion of dextran.

In the pre-infusion series with Swedish dextran, significant correlations between the presence of $2 \mu \mathrm{g}$. of antibody $\mathrm{N}$ or more per ml. precipitable by native dextrans NRRL B742, NRRL B512 and Swedish 3079 were found. In the post-infusion series significant correlations were found with these dextrans and with NRRL B1254. In Experiment 2 in which Commercial Solvents dextran was infused, significant correlations were found between systemic reactions and the presence of $2 \mu \mathrm{g}$. or more of antibody $\mathrm{N}$ per ml. precipitable by native B512, clinical Commercial Solvents dextran and clinical Swedish dextran. No correlation with any dextran appeared in the post-infusion sera.

It should be noted that as previously reported $(10,11)$ the quantities of antibody $\mathrm{N}$ precipitable from a given serum specimen by the various dextrans were not identical, but the dextrans with the highest proportion of non $1 \rightarrow 6$ linkages precipitated considerably more antibody than did those with fewer non $1 \rightarrow 6$ linkages. Native dextran NRRL B742 with the lowest nitrogen content precipitated the most antibody of the various 
TABLE III

Relation of circulating precipitins to various dextrans before and one month after infusion of dextran and allergic reactions encountered on infusion

\begin{tabular}{|c|c|c|c|c|c|c|c|c|c|c|}
\hline \multirow{2}{*}{$\begin{array}{c}\text { Dextran } \\
\text { uesed for } \\
\text { precipitin } \\
\text { test }\end{array}$} & \multirow{2}{*}{$\begin{array}{c}\text { Pre- } \\
\text { infueion } \\
\text { precipitin } \\
\text { level }\end{array}$} & \multicolumn{2}{|c|}{ Systemic reaction } & \multirow[b]{2}{*}{$x^{2}$} & \multirow[b]{2}{*}{$\mathbf{P}$} & \multirow{2}{*}{$\begin{array}{l}\text { Precipitin } \\
\text { levels one } \\
\text { month post- } \\
\text { infusion }\end{array}$} & \multicolumn{2}{|c|}{ Systemic reaction } & \multirow[b]{2}{*}{$x^{2}$} & \multirow[b]{2}{*}{$\mathbf{P}$} \\
\hline & & Negative & Positive & & & & Negative & Pooitive & & \\
\hline \multicolumn{11}{|c|}{ Experiment $1-$ Infusion Swedish Dextran } \\
\hline $\begin{array}{l}\text { Native Swedish } \\
3079\end{array}$ & $\begin{array}{l}0-1.9 \\
2.0 \text { or more }\end{array}$ & $\begin{array}{r}39 \\
6\end{array}$ & $\begin{array}{l}31 \\
15\end{array}$ & 4.0 & 0.046 & $\begin{array}{l}0-1.9 \\
2.0 \text { or more }\end{array}$ & $\begin{array}{r}29 \\
4\end{array}$ & $\begin{array}{l}22 \\
13\end{array}$ & 5.1 & 0.024 \\
\hline NRRL B1254 & $\begin{array}{l}0-1.9 \\
2.0 \text { or more }\end{array}$ & $\begin{array}{r}41 \\
3\end{array}$ & $\begin{array}{r}43 \\
1\end{array}$ & & & $\begin{array}{l}0-1.9 \\
2.0 \text { or more }\end{array}$ & $\begin{array}{r}30 \\
2\end{array}$ & $\begin{array}{l}24 \\
10\end{array}$ & 6.2 & 0.013 \\
\hline NRRL B742 & $\begin{array}{l}0-1.9 \\
2.0 \text { or more }\end{array}$ & $\begin{aligned} 39 \\
7\end{aligned}$ & $\begin{array}{l}14 \\
32\end{array}$ & 26.6 & 0.00004 & $\begin{array}{l}0-1.9 \\
2.0 \text { or more }\end{array}$ & $\begin{array}{l}20 \\
13\end{array}$ & $\begin{array}{r}9 \\
25\end{array}$ & 8.8 & 0.0038 \\
\hline $\begin{array}{l}\text { NRRL B512 } \\
\text { (Native Commer- } \\
\text { cial Solvents) }\end{array}$ & $\begin{array}{l}0-1.9 \\
2.0 \text { or more }\end{array}$ & $\begin{array}{r}44 \\
2\end{array}$ & $\begin{array}{l}35 \\
11\end{array}$ & 5.8 & 0.016 & $\begin{array}{l}0-1.9 \\
2.0 \text { or more }\end{array}$ & $\begin{array}{r}31 \\
2\end{array}$ & $\begin{array}{l}20 \\
15\end{array}$ & 11.3 & $<0.002$ \\
\hline Clinical Swedish & $\begin{array}{l}0-1.9 \\
2.0 \text { or more }\end{array}$ & $\begin{array}{r}44 \\
2\end{array}$ & $\begin{array}{r}44 \\
2\end{array}$ & & & $\begin{array}{l}0-1.4 \\
2.0 \text { or more }\end{array}$ & $\begin{array}{r}33 \\
1\end{array}$ & $\begin{array}{r}31 \\
4\end{array}$ & 1.9 & 0.16 \\
\hline $\begin{array}{l}\text { Clinical Commer- } \\
\text { cial Solvents }\end{array}$ & $\begin{array}{l}0-1.9 \\
2.0 \text { or more }\end{array}$ & $\begin{array}{r}46 \\
0\end{array}$ & $\begin{array}{r}45 \\
1\end{array}$ & & & $\begin{array}{l}0-1.9 \\
2.0 \text { or more }\end{array}$ & $\begin{array}{r}35 \\
0\end{array}$ & $\begin{array}{r}31 \\
3\end{array}$ & 3.1 & 0.07 \\
\hline \multicolumn{11}{|c|}{ Experiment 2-Infusion Commercial Solvents Dextran } \\
\hline $\begin{array}{l}\text { Native Swedish } \\
3079\end{array}$ & $\begin{array}{l}0-1.9 \\
2.0 \text { or more }\end{array}$ & $\begin{array}{l}60 \\
28\end{array}$ & $\begin{array}{l}8 \\
9\end{array}$ & 2.6 & 0.11 & $\begin{array}{l}0-1.9 \\
2.0 \text { or more }\end{array}$ & $\begin{array}{l}63 \\
26\end{array}$ & $\begin{array}{r}10 \\
5\end{array}$ & 0.39 & 0.53 \\
\hline NRRL B1254 & $\begin{array}{l}0-1.9 \\
2.0 \text { or more }\end{array}$ & $\begin{array}{l}54 \\
32\end{array}$ & $\begin{array}{l}9 \\
8\end{array}$ & $<0.3$ & & $\begin{array}{l}0-1.9 \\
2.0 \text { or more }\end{array}$ & $\begin{array}{l}75 \\
13\end{array}$ & $\begin{array}{r}12 \\
2\end{array}$ & 0 & \\
\hline NRRL B742 & $\begin{array}{l}0-1.9 \\
2.0 \text { or more }\end{array}$ & $\begin{array}{l}27 \\
59\end{array}$ & $\begin{array}{r}2 \\
16\end{array}$ & 3.1 & 0.08 & $\begin{array}{l}0-1.9 \\
2.0 \text { or more }\end{array}$ & $\begin{array}{l}30 \\
59\end{array}$ & $\begin{array}{l}5 \\
9\end{array}$ & $\mathbf{0}$ & \\
\hline $\begin{array}{l}\text { NRRL B512 } \\
\text { (Native Commer- } \\
\text { cial Solvents) }\end{array}$ & $\begin{array}{l}0-1.9 \\
2.0 \text { or more }\end{array}$ & $\begin{array}{l}57 \\
31\end{array}$ & $\begin{array}{r}6 \\
12\end{array}$ & 7.3 & $<0.009$ & $\begin{array}{l}0-1.9 \\
2.0 \text { or more }\end{array}$ & $\begin{array}{l}67 \\
22\end{array}$ & $\begin{array}{r}12 \\
3\end{array}$ & 0.4 & \\
\hline Clinical Swedish & $\begin{array}{l}0-1.9 \\
2.0 \text { or more }\end{array}$ & $\begin{array}{l}75 \\
12\end{array}$ & $\begin{array}{r}12 \\
6\end{array}$ & 4.3 & 0.04 & $\begin{array}{l}0-1.9 \\
2.0 \text { or more }\end{array}$ & $\begin{array}{r}85 \\
4\end{array}$ & $\begin{array}{r}14 \\
0\end{array}$ & $\mathbf{0}$ & \\
\hline $\begin{array}{l}\text { Clinical Commer- } \\
\text { cial Solvents }\end{array}$ & $\begin{array}{l}0-1.9 \\
2.0 \text { or more }\end{array}$ & $\begin{array}{r}86 \\
2\end{array}$ & $\begin{array}{r}14 \\
4\end{array}$ & 11.4 & 0.002 & $\begin{array}{l}0-1.9 \\
2.0 \text { or more }\end{array}$ & $\begin{array}{r}87 \\
2\end{array}$ & $\begin{array}{r}14 \\
1\end{array}$ & 0 & \\
\hline
\end{tabular}

native dextrans used. From the nitrogen content, moreover, the amounts of protein which could have been added in the quantitative precipitin tests were so small that any protein-antibody complex would have remained in solution. The clinical dextrans precipitated much less antibody than did the native dextrans. This may be seen in Table III, Experiment I, in which for pre-infusion sera the proportion of individuals showing two or more micrograms antibody $\mathrm{N}$ per $\mathrm{ml}$. was 42 per cent for B742, 23 per cent for native Swedish 3079, 5 per cent for native B1254 and 14 per cent for native B512, while for clinical Swedish and clinical Commercial Solvents dextrans the percentages were 4 and 1 , respectively. In the pre-infusion serum samples of Experiment 2, the corresponding values for the native dextrans were $72,35,39$ and 41 , while for the clinical dextrans they were 17 and 6 per cent, respectively. It is especially significant that just as the individuals in the second experiment showed an increased incidence of positive skin tests so did they show an increased level of precipitating antibodies.

Figure 2 shows a series of scattergrams indicating the relationship between initial skin sensitivity and pre-infusion or post-infusion antidextran levels to B742 with the systemic allergic reactions experienced. It is evident that individuals who showed a high degree of skin sensitivity or a high level of pre-existing precipitating antibody 
tended to have positive systemic allergic reactions. The striking difference in the incidence of allergic reactions on infusion of Swedish dextran as compared with Commercial Solvents dextran is evident. Moreover, inspection of the upper and lower scattergrams with Swedish dextran shows a substantial shift toward the appearance of higher levels of circulating precipitins one month after infusion. On the other hand, the similar comparison of the upper and lower scattergrams obtained with Commercial Solvents dextran shows a trend toward the existence of lower antidextran levels to B742 one month after infusion. Thus it would appear that infusion of Swedish clinical dextran provoked an anamnestic rise in antidextran level one month following infusion, while similar infusion of Commercial Solvents dextran generally had no such effect. Four individuals in the latter group showed an anamnestic rise of over $2 \mu \mathrm{g}$. of antibody $\mathrm{N}$ per $\mathrm{ml}$. as compared with fifteen individuals in the former group. Twenty individuals in the second experiment showed a decline of 2 $\mu g$. antibody $\mathrm{N}$ per ml. or greater, as compared with seven individuals in the first experiment. Scattergrams similar to those in Figure 2 for native Swedish dextran and native Commercial Solvents dextran were obtained.

A group of 33 individuals who had received infusions either of Swedish dextran or of Commercial Solvents dextran 4 to 23 months previously in the studies of Pulaski, Baker, Tarrow, and Amspacher $(3,4)$ volunteered to undergo skin testing and a second infusion of dextran. Table IV shows the distribution of skin sensitivity to the various dextrans. Comparison of the results in Table II for Experiment 2 done at the same time shows no essential difference in the incidence of skin sensitivity. Quantitative precipitin studies on serum taken prior to the second infusion showed no significant differences in antibody level as compared to the groups which had not been previously infused. Table $\mathrm{V}$ shows that prior

\section{RELATION BETWEEN INITIAL SKIN SENSITIVITY, INITIAL ANTIDEXTRAN LEVEL AND ALLERGIC REACTIONS TO INFUSION OF DEXTRAN}

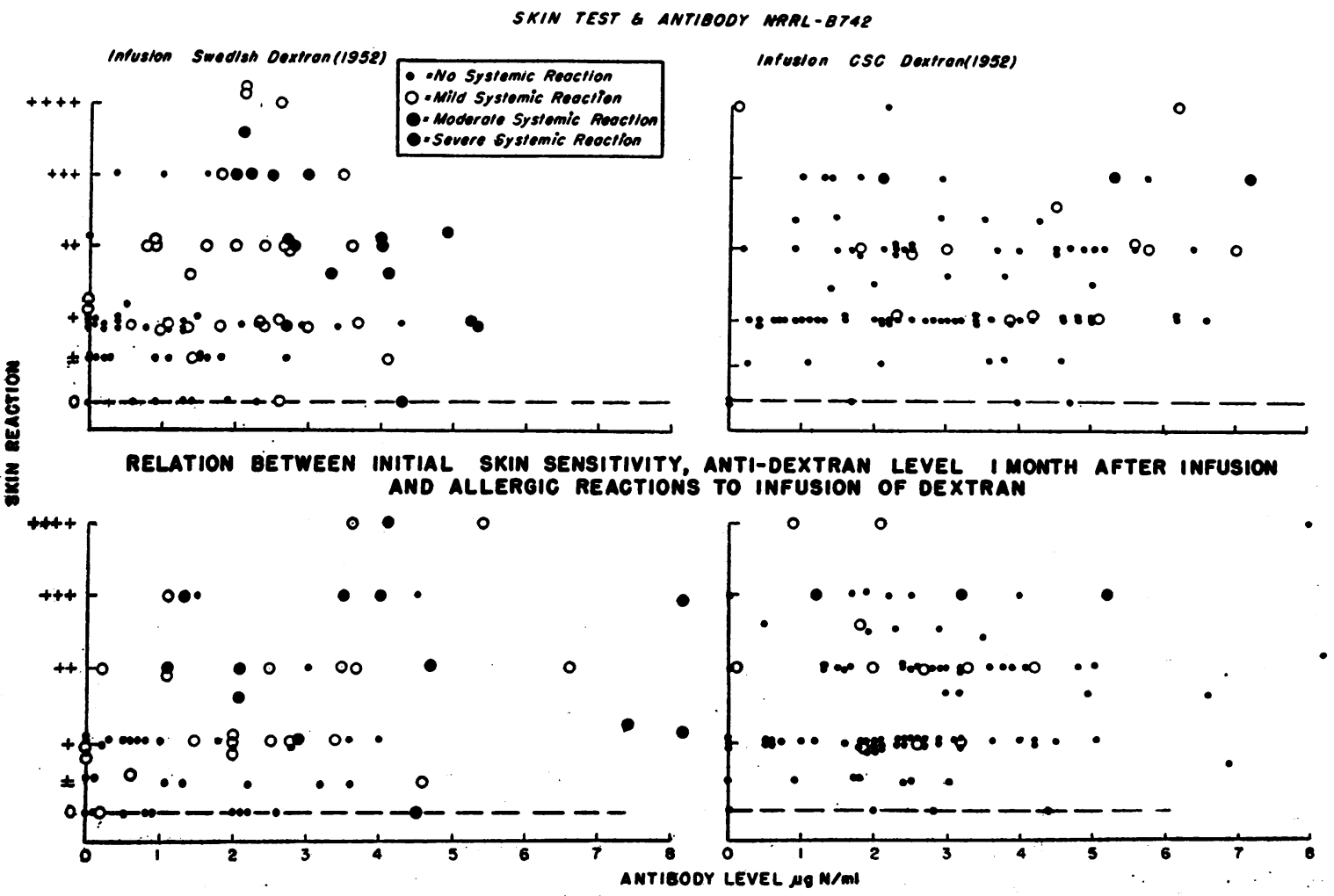

Figure 2 
TABLE IV

Distribution of skin tests prior to re-infusion in 33 individuals previously infused with dextran

\begin{tabular}{|c|c|c|c|c|c|c|}
\hline \multirow[b]{2}{*}{ Dextran } & \multicolumn{6}{|c|}{$\frac{\text { Degree of skin sensitivity }}{\text { (Number of individuals) }}$} \\
\hline & - & \pm & + & ++ & +++ & $+++t$ \\
\hline $\begin{array}{l}\text { Native Swedish } 3079 \\
\text { NRRL B1255 } \\
\text { NRRL B742 } \\
\text { NRRL B512 } \\
\text { Clinical Swedish } \\
\text { Leuconostoc protein }\end{array}$ & $\begin{array}{r}14 \\
9 \\
7 \\
23 \\
25 \\
0\end{array}$ & $\begin{array}{l}0 \\
6 \\
3 \\
2 \\
4 \\
0\end{array}$ & $\begin{array}{r}18 \\
13 \\
13 \\
7 \\
4 \\
25\end{array}$ & $\begin{array}{l}1 \\
5 \\
8 \\
1\end{array}$ & 1 & 1 \\
\hline
\end{tabular}

infusion of either Swedish or Commercial Solvents dextran within the time interval studied did not result in any enhanced susceptibility to allergic reactions on re-infusion of dextran. Three of the four positive reactions which resulted on re-infusion of Swedish dextran were of the same degree of severity as had previously been noted from the first infusion of Swedish dextran. The fourth individual showed only one hive from the second infusion.

\section{DISCUSSION}

The results outlined above clearly established that it is possible to produce a dextran suitable for clinical use which gives a low incidence of allergic reactions in a population, a large proportion of which showed initial skin sensitivity of the wheal and erythema type and whose sera contained precipitating antibodies to dextran. This preparation from a strain of Leuconostoc (NRRL B512) yielded a dextran having the lowest incidence of non- $1 \rightarrow 6$ linkages (15) and hence was the most linear dextran available. Furthermore, in the random population native dextran from this strain showed the lowest incidence of wheal and erythema skin reactions of any of the native dextrans tested. With respect to circulating precipitins, however, the number of individuals showing two or more micrograms of antibody $\mathrm{N}$ per $\mathrm{ml}$. was about the same for native Swedish, native B512 and native B1254 dextrans and these were considerably fewer than the number of individuals showing 2 or more micrograms of antibody $\mathrm{N}$ per $\mathrm{ml}$. with B742. Partial hydrolysis of Swedish or Commercial Solvents dextrans to produce a dextran

TABLE V

Incidence of adverse systemic reactions to a second infusion of dextran

\begin{tabular}{|c|c|c|c|c|c|c|c|}
\hline \multirow{2}{*}{$\begin{array}{c}\text { Initial } \\
\text { dextran } \\
\text { infusion }\end{array}$} & \multirow{2}{*}{$\begin{array}{c}\text { Interval } \\
\text { following } \\
\text { first } \\
\text { infusion }\end{array}$} & \multirow{2}{*}{$\begin{array}{c}\text { Dextran } \\
\text { re-infused }\end{array}$} & \multirow{2}{*}{$\begin{array}{l}\text { Number of } \\
\text { individuals }\end{array}$} & \multicolumn{3}{|c|}{ Reactions } & \multirow{2}{*}{$\begin{array}{l}\text { Incidence } \\
\text { of reactions }\end{array}$} \\
\hline & & & & Mild & Moderate & Severe & \\
\hline \multirow{4}{*}{$\begin{array}{l}\text { Commercial } \\
\text { Solvents } \\
\text { Commercial } \\
\text { Solvents } \\
\text { Swedish }\end{array}$} & (months) & & & & & & \\
\hline & $4 \frac{1}{2}$ & Commercial & $10^{*}, \dagger$ & 0 & 0 & 0 & $0 / 10$ \\
\hline & $9 \frac{1}{2}$ to 23 & Commercial & 7 & 0 & 0 & 0 & $0 / 7$ \\
\hline & 11 to 21 & $\begin{array}{c}\text { Commercial } \\
\text { Solvents }\end{array}$ & $7 \pm .8$ & 0 & 0 & 0 & $0 / 7$ \\
\hline English & 17 & $\begin{array}{c}\text { Commercial } \\
\text { Solvents }\end{array}$ & 1 & 0 & 0 & 0 & $0 / 1$ \\
\hline Swedish & 11 to 21 & Swedish & $8 \|$ & 2 & 1 & 1 & $4 / 8$ \\
\hline
\end{tabular}

* One individual had received two previous infusions of Commercial Solvents dextran, one 11 months and the other $4 \frac{1}{2}$ months earlier.

One individual had had a severe reaction to the initial infusion of Commercial Solvents dextran.

F One individual had received two previous infusions of dextran, one of Swedish dextran 12 months and the other of Commercial Solvents dextran 11 months earlier.

8 Two of these individuals had had a severe and a mild reaction on initial infusion of Swedish dextran $13 \frac{1}{2}$ months earlier.

Three of these individuals had had severe, mild and moderate reactions to an initial infusion of Swedish dextran 18,13 , and 5 months earlier. The same three individuals experienced similar reactions to re-infusion of dextran. 
suitable for use as a plasma volume expander produced a dramatic reduction in the capacity of the material to induce wheal and erythema reactions or to precipitate the circulating antidextran in the same population (Tables II and III). It is noteworthy that the dextran which produced the lowest incidence of allergic reactions (CSC 255F4) had been sharply fractionated to remove materials of high molecular weight, while the dextran which gave the high incidence of allergic reactions (Swedish) had not been so fractionated and contained appreciable quantities of materials with very high molecular weights. The lot containing intermediate-sized material (CSC 258A7) gave two severe reactions in thirty individuals tested. In an independent study, Kabat and Bezer (18) have shown that a substantial decrease in antigenicity of B512 dextran occurs with molecular weights below 90,000 , and Maurer (12) has reported definite antigenicity for dextran 258A7 obtaining levels of about 10 or more $\mu g$. antibody $\mathrm{N}$ per ml. in three of six individuals injected. It would then appear that choice of dextran producing microorganism, degree of hydrolysis, and extent of removal of high molecular weight constituents are important factors in the manufacture of reaction-free dextran.

The occurrence of precipitins to dextran and of initial skin sensitivity to dextran in the population raise the question as to the origin of these antibodies. Since dextran has been shown by Neill, Hehre, Sugg, and Jaffe $(19,20)$ to be a contaminant of commercial sugar, and since these workers have isolated dextran-producing organisms from the gastrointestinal tract $(21,22)$, ample opportunity exists for the development of an antibody response. Furthermore, since dextrans are known to cross-react with Types II, XII, XX, IX, $\mathrm{XXII}$, etc. rabbit and horse antipneumococcal sera $(19,20,23)$, the precipitable antibody and skin sensitivity to dextran in human subjects may theoretically in some instances be attributable to previous contact or infection with these organisms. On the other hand, Maurer (12) found that immunization of humans with dextran did not affect the Type II, XII or XX antipolysaccharide levels, nor did absorption with Type II, XII, or XX pneumococcal polysaccharides reduce the antidextran level. It is not surprising that a linear dextran should give a lower incidence of skin sensitivity than a more highly branched dextran, since the latter would possess a multiplicity of structures not present in the former and thus would increase the probability of its being able to react with antibodies produced to the heterogenous array of antigenic stimuli encountered at random in the human environment.

Although the data clearly indicate a high statistical correlation between initial skin sensitivity to native dextrans and systemic allergic reactions, there are a sufficient number of exceptions so that the single skin test of 10 to 20 micrograms of dextran was of little prognostic significance in evaluating the occurrence of allergic reaction in response to injection of $30 \mathrm{Gm}$. of dextran. This is not surprising since a) the nature of the antigen to which the initial skin sensitivity developed is not known and, in all probability, is not the same as that used for skin test and infusion; b) the ratio of the infused dose to the skin test dose is unusually high, of the order of three million; c) only a single skin test dose was used.

Similar considerations obviously apply to the individual cases in which precipitating antibody levels and allergic reactions did not run parallel, although again a high statistical correlation was observed between these levels and allergic reactions. Thus the capacity of the various dextrans to precipitate the multiplicity of antibodies resulting from the unknown antigenic stimuli and the necessarily limited capacity to establish optimum quantities of dextran for precipitating these antibodies in the quantitative precipitin studies would contribute substantially to such individual variations.

The finding of an anamnestic rise in antibody level one month after infusion of Swedish dextran in a considerable proportion of individuals while no such rise was observed following infusion of Commercial Solvents dextran is in accord with evidence suggesting that the latter is less antigenic in man, although MacLeod (24) has found that the pneumococcus polysaccharides are capable of eliciting an anamnestic response in the rabbit despite their inability to produce a primary antibody response.

While the limited re-infusion data indicate that dextran may be re-infused up to 23 months following an initial infusion without difficulty, it is obviously impossible to extrapolate to periods be- 
yond this. The generally lower antigenicity of the current commercial preparations of dextran prepared from the B512 strain according to American specifications provide additional assurance of its probable safety for clinical use. It should be emphasized that the Swedish preparations herein described were in use in 1951-1952. The current preparations of Swedish dextran differ in two important respects from these older preparations in that they are prepared from the B512 strain and are more sharply fractionated to remove high molecular weight constituents.

\section{SUMMARY}

1. A detailed protocol for elucidating the relationship between skin sensitivity and precipitating antibody in the random population to a carbohydrate antigen and their relation to the occurrence of allergic reactions on intravenous administration is described.

2. Significant correlations were established between a) initial skin sensitivity to certain native dextrans and the occurrence of systemic allergic reactions on administration of Swedish dextran; b) the presence in human sera of antibodies specifically precipitable by certain dextrans and the occurrence of systemic allergic reactions to clinical Swedish dextran; c) the structural complexity of native dextrans and the incidence of positive skin sensitivity in the random population.

3. Partial hydrolysis of native dextrans to the molecular weight range suitable for clinical use results in a striking diminution in their capacity to produce a positive wheal and erythema reaction in man.

4. In a population of comparable skin sensitivity and antibody levels a preparation of clinical dextran (Commercial Solvents) was encountered which gave a very low incidence of systemic allergic reactions. This appeared to be correlated with the selection of a strain of Leuconostoc mesenteroides (NRRL B512) producing a dextran with an unusually low proportion of non $1 \rightarrow 6$ linkages and with the elimination of materials of higher molecular weight range by fractional precipitation to give a product with a narrower molecular weight distribution.

5. In a small series of individuals receiving reinfusion of both Swedish and Commercial Sol- vents dextran no evidence of increased sensitization was found during an interval of up to 23 months between the two infusions.

\section{ACKNOWLEDGMENTS}

The authors are indebted to the following individuals who were serving at that time in the Armed Forces: Lt. Col. Irving Gray, Lt. Col. C. Artz, Major S. Gaines, Captains A. L. Gropper, M. C. Creditor, L. G. Raisz, Lieutenants F. Goldner, R. Nelson, K. Stevens, and G. Gorda of the Surgical Research Unit, Brooke Army Hospital, and to Lieutenant T. Cloud of the Walter Reed Army Medical Center. They are also grateful for the advice and assistance of Drs. F. D. Lawrason and M. H. Sloan of the National Research Council.

\section{REFERENCES}

1. Bohmansson, G., Rosenkvist, H., Thorsén, G., and Wilander, O., Clinical experiences with dextran as a plasma substitute. Acta chir. Scandinav., 1946, 94, 149.

2. Turner, F. P., Butler, B. C., Smith, M. E., and Scudder, J., Dextran, an experimental plasma substitute. Surg., Gynec. \& Obst., 1949, 88, 661.

3. Pulaski, E. J., Baker, H. J., Tarrow, A. B., and Amspacher, W. H., Reports to the National Research Council Subcommittee on Shock, 1951.

4. Tarrow, A. B., Dextran-a plasma substitute. Thesis, Baylor University, 1951.

5. Grönwall, A., and Ingelman, B., Untersuchungen über Dextran und sein Verhalten bei parenteraler Zufuhr. I. Acta physiol. Scandinav., 1944, 7, 97.

6. Bull, J. P., Ricketts, C., Squire, J. R., Maycock, W., d'A., Spooner, S. J. L., Mollison, P. L., and Paterson, J. C. S., Dextran as a plasma substitute. Lancet, 1949, I, 134.

7. Vorhees, A. B., Baker, H. J., and Pulaski, E. J., Reactions of albino rats to injections of dextran. Proc. Soc. Exper. Biol. \& Med., 1951, 76, 254.

8. Morrison, J. L., Bloom, W. L., and Richardson, A. P., Effect of dextran on the rat. J. Pharmacol. \& Exper. Therap., 1951, 101, 27.

9. Morrison, J. L., Richardson, A. P., and Bloom, W. L., The effects of antihistaminic agents on the reaction of the rat to dextran. Arch. internat. de pharmacodyn. et de thérap., 1951, 88, 98.

10. Kabat, E. A., and Berg, D., Production of precipitins and cutaneous sensitivity in man by injection of small amounts of dextran. Ann. New York Acad. Sc., 1952, 55, 471.

11. Kabat, E. A., and Berg, D., Dextran-an antigen in man. J. Immunol., 1953, 70, 514.

12. Maurer, P. H., Dextran, an antigen in man. Proc. Soc. Exper. Biol. \& Med., 1953, 83, 879.

13. Grabar, P., Reactions de divers sêrum normaux avec des substances macromoléculaires naturelles ou synthétiques. Ann. Inst. Pasteur, 1955, 88, 11. 
14. Senti, F., Northern Regional Laboratory. Personal communication to Dr. M. H. Sloan, National Research Council, 1956.

15. Jeanes, A., Haynes, W. C., Wilham, C. A., Rankin, J. C., Melvin, E. H., Austin, M. J., Cluskey, J. E., Fisher, B. E., Tsuchiya, H. M., and Rist, C. E., Characterization and classification of dextrans from ninety-six strains of bacteria. J. Am. Chem. Soc., 1954, 76, 5041.

16. Ingelman, B., and Halling, M. S., Some physicochemical experiments on fractions of dextran. Ark. Kemi, 1949, 1, 61.

17. Heidelberger, M., and MacPherson, C. F. C., Quantitative micro-estimation of antibodies in the sera of man and other animals. Science, 1943, 97, 405; 98, 63.

18. Kabat, E. A., and Bezer, A. E., In preparation.

19. Neill, J. M., Hehre, E. J., Sugg, J. Y., and Jaffe, E., Serological studies on sugar. I. Reactions between solutions of reagent sucrose and Type II antipneumococcus serum. J. Exper. Med., 1939, 70, 427.

20. Sugg, J. Y., and Hehre, E. J., Reactions of dextrans of Leuconostoc mesenteroides with the antiserums of Leuconostoc and of Types 2, 20 and 12 pneumococcus. J. Immunol., 1942, 43, 119.

21. Hehre, E. J., and Neill, J. M., Formation of serologically reactive dextrans by streptococci from subacute bacterial endocarditis. J. Exper. Med., 1946, 83, 147.

22. Neill, J. M., Sugg, J. Y., Hehre, E. J., and Jaffe, E., Influence of sucrose upon production of serologically reactive material by certain streptococci. Proc. Soc. Exper. Biol. \& Med., 1941, 47, 339.

23. Heidelberger, M., and Aisenberg, A. C., Serological reactivity of synthetic polyglucoses. Proc. Nat. Acad. Sc., 1953, 39, 453.

24. MacLeod, C. M., Personal communication. 